\title{
Metallothionein in Pancreatic Endocrine Neoplasms
}

Tatsuo Tomita

Department of Pathology, University of Kansas Medical Center, Kansas City, Kansas

Metallothioneins (MTs) are intracellular proteins that bind to metal ions and are involved in heavy metal homeostasis and detoxification. Pancreatic islets were shown to be positive for zinc-containing matrix metalloproteinase-2 and -9 by immunocytochemical staining. The immunolocalization of matrix metalloproteinases in pancreatic islets prompted us to study further the link between zinc and MT in 34 cases of pancreatic endocrine neoplasms, including insulinomas, glucagonomas, gastrinomas, pancreatic polypeptide-omas, and nonfunctioning endocrine neoplasms. Four types of islet cells were found to be positive for MT, whereas pancreatic endocrine neoplasms mostly were either weakly positive or negative for MT. The presence of MT in normal islet cells and pancreatic endocrine neoplasms is consistent with the notion that MTs modulate zinc homeostasis and metabolism in pancreatic islet cells and pancreatic endocrine neoplasms as those tissues contain zinc-containing matrix metalloproteinases.

KEY WORDS: Immunocytochemistry, Metallothionein, Pancreatic endocrine neoplasms, Pancreatic islets.

Mod Pathol 2000;13(4):389-395

Metallothioneins (MTs) are low molecular weight (6000 to 7000) intracellular proteins, generally containing 61 amino acid residues (1). Because of the presence of 20 cysteines in the MT molecule, a total of 7 equivalents of bivalent metal ions (1), including zinc, copper, cadmium, mercury, and platinum, can be bound (2). MTs thus are involved in homeostasis of essential metals, including zinc and copper (2). MTs are found in normal mammalian tissues such as thymulin-containing thymic epithelial cells, myoepithelial cells (3), germinative cells and eccrine sweat coil cells of skin $(3,4)$, and Sertoli

Copyright (C) 2000 by The United States and Canadian Academy of Pathology, Inc.

VOL. 13, NO. 4, P. 389, 2000 Printed in the U.S.A.

Date of acceptance: September 27, 1999.

Address reprint requests to: Tatsuo Tomita, M.D., Department of Pathology, University of Kansas Medical Center, 3901 Rainbow Boulevard, Kansas City, KS 66160. cells (5) and parenchymal cells of liver, kidney, and lung $(2,5,6)$. Pancreatic $\beta$ islet cells are known to use zinc to form the insulin dimer within $\beta$ islet cell granules (7-9). Both zinc-containing matrix metalloproteinase (MMP) -2 and -9 and tissue inhibitor of metalloproteinase- 1 and -2 have been immunocytochemically localized in $\beta$ cells, non- $\beta$ cells, and pancreatic endocrine neoplasms (10). Furthermore, the cytosols of pancreatic endocrine neoplasms, including those of insulinomas and glucagonomas, have showed high levels of MMPs and tissue inhibitors of metalloproteinase using enzyme immunoassays (11). More recent, we have detected immunoreactive MT in human pancreatic islets and pursued to immunocytochemically localize MT in pancreatic endocrine neoplasms.

\section{MATERIALS AND METHODS}

A total of 34 cases of pancreatic endocrine neoplasms were collected from surgically resected cases and autopsy cases at the University of Kansas Medical Center between 1974 and 1998, consisting of 12 insulinomas, 3 glucagonomas, 10 gastrinomas, 6 pancreatic polypeptide (PP)-omas, and three nonfunctioning endocrine neoplasms. All tissues initially were fixed in $10 \%$ neutral formalin and were embedded in paraffin. Deparaffinized serial tissue sections were treated with citrate buffer $(0.1$ $\mathrm{N}, \mathrm{pH}$ 6) for $10 \mathrm{~min}$ in a microwave oven (12). The four pancreatic hormones-insulin, glucagon, somatostatin release-inhibiting factor, and $\mathrm{PP}$-as well as gastrin and chromogranin A were stained in serial tissue sections using avidin-biotin peroxidase method as reported previously $(10,11,13)$. MT immunostaining was performed with rabbit antimouse MT I antibody (1:500 dilution), and avidinbiotin alkaline phosphatase method was used as reported (14). This polyclonal antibody was raised against synthetic peptide corresponding to the terminal 15 amino acids of mouse MT I $(14,16)$. A similar antiserum was previously used for immunocytochemical staining with mouse pancreatic islets (17). 


\section{RESULTS}

\section{Normal Pancreatic Islets}

The consecutive sections were systematically stained for the four pancreatic hormones, gastrin, chromogranin A, and MT, and the staining patterns were compared between pancreatic hormones and MT. The normal islets from the tail portion showed numerous, centrally located insulin cells, peripherally located glucagon cells, scattered somatostatin release-inhibiting factor cells, and a few PP cells by the immunoperoxidase method. All four kinds of islet cells were positively stained for MT by the alkaline phosphatase method. The smaller islets from the head portion revealed insulin cells in the middle portion of the islets, which positively stained for MT, whereas the less numerous glucagon cells showed partial MT stains, and many PP cells at the periphery of the islets stained lesser for MT (Fig. 1).

\section{Pancreatic Endocrine Neoplasms}

The patterns of MT immunostaining were compared between normal islets from adjacent pancreatic tissue and endocrine neoplasms. Among 12 cases of insulinomas, including 1 malignant one, 10 cases were moderately stained and 2 cases were weakly stained for insulin, whereas all insulinomas were less stained for MT compared with normal islet cell staining (Table 1). Three and eight cases were moderately and weakly positive for MT, re-
A
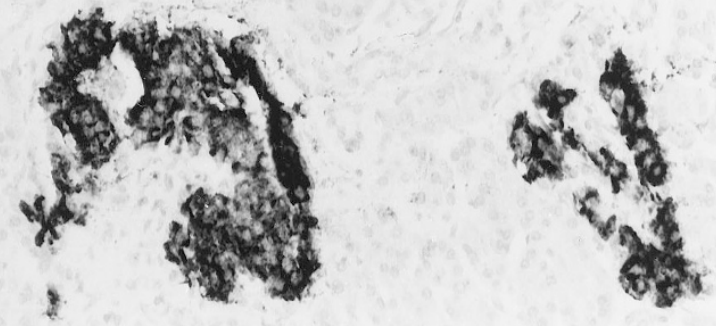

C

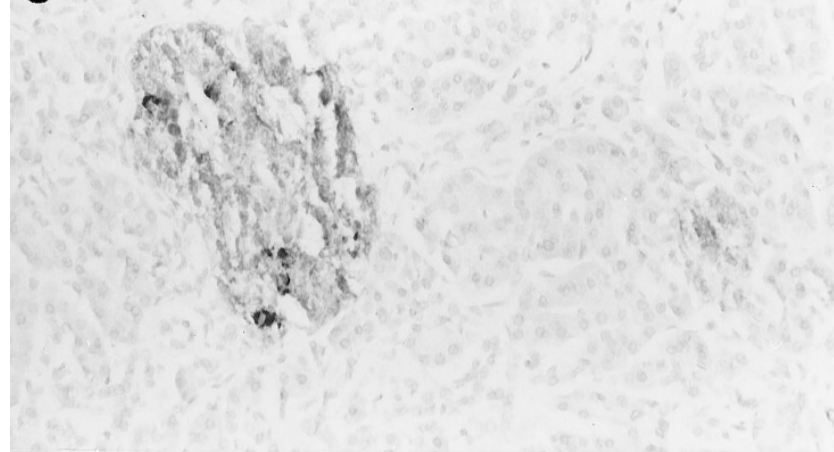

B

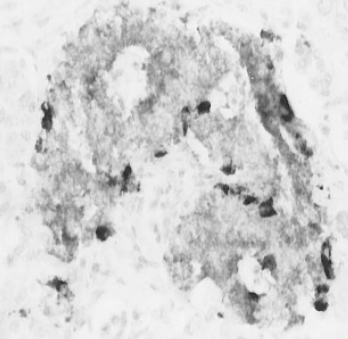

D

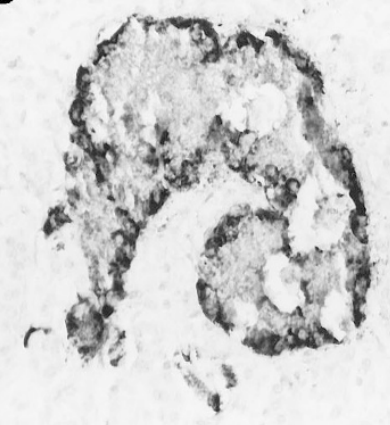

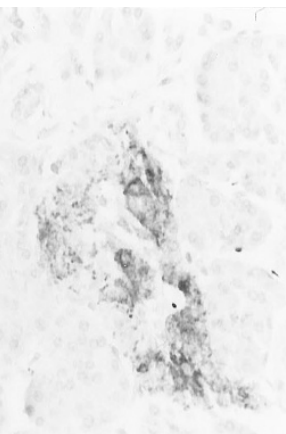

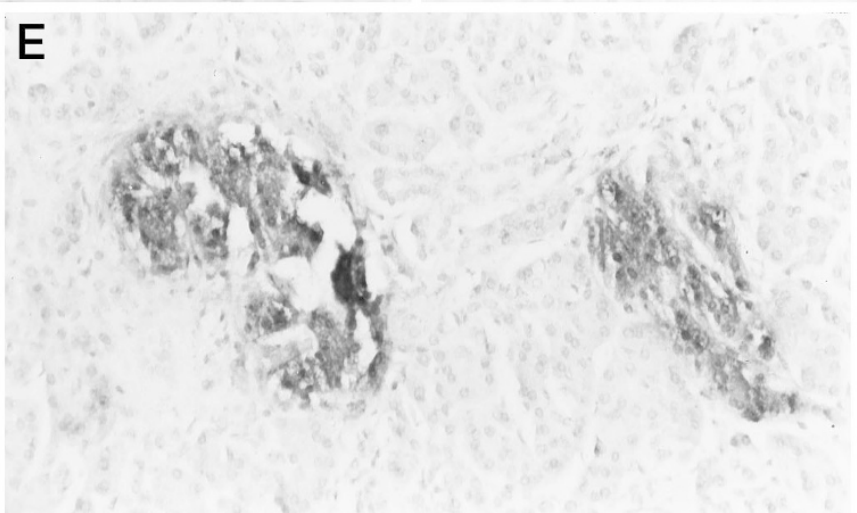

FIGURE 1. Two islets from head portion of normal pancreas. Insulin cells were mostly centrally located whereas glucagon cells and a few somatotropin release-inhibiting factor cells were scattered in the islets, and numerous PP cells were peripherally located. MT staining corresponded mostly to that of insulin cells. Immunostained for insulin (A), glucagon (B), somatostatin release-inhibiting factor (C), pancreatic polypeptide (D), and metallothionein $(\mathbf{E})(265 \times)$. 
TABLE 1. Summary of Islet Cell Tumors and MT Immunostaining in Insulinomas

\begin{tabular}{|c|c|c|c|c|c|c|c|}
\hline \multirow{2}{*}{ Case No. } & \multirow{2}{*}{ Age/Sex } & \multirow{2}{*}{ Location } & \multirow{2}{*}{ Size $(\mathrm{cm})$} & \multicolumn{2}{|c|}{ Insulin Staining } & \multicolumn{2}{|c|}{ MT Staining } \\
\hline & & & & Islets & Tumor & Islets & Tumor \\
\hline 1 & $17 / \mathrm{F}$ & Head & $1.5 \times 1.0$ & +++ & + & +++ & - \\
\hline 2 & $19 / \mathrm{F}$ & Body & $1.5 \times 1.5$ & +++ & ++ & ++ & + \\
\hline 3 & $20 / \mathrm{F}$ & Tail & $1.8 \times 1.8$ & +++ & ++ & ++ & + \\
\hline 4 & $47 / \mathrm{F}$ & Head & $0.7 \times 0.5$ & +++ & ++ & ++ & + \\
\hline 5 & $52 / \mathrm{M}$ & Tail & $1.2 \times 1.0$ & +++ & ++ & ++ & + \\
\hline 6 & $64 / \mathrm{F}$ & Tail & $7.0 \times 7.0$ & +++ & + & ++ & + \\
\hline 7 & $68 / \mathrm{F}$ & Head & $1.7 \times 1.5$ & +++ & ++ & ++ & + \\
\hline $8^{*}$ & $68 / \mathrm{F}$ & Body/Tail & $6.5 \times 6.0$ & +++ & ++ & ++ & ++ \\
\hline $9 *$ & $71 / \mathrm{F}$ & Liver metastasis & & NA & ++ & NA & ++ \\
\hline $10^{a}$ & $71 / \mathrm{M}$ & Head & $1.4 \times 1.2$ & +++ & ++ & ++ & ++ \\
\hline 11 & $79 / \mathrm{F}$ & Head & $1.5 \times 1.4$ & +++ & ++ & ++ & + \\
\hline 12 & $84 / \mathrm{F}$ & Body & $1.7 \times 1.3$ & +++ & ++ & ++ & + \\
\hline
\end{tabular}

MT, metallothionein; +++ , strongly stained; ++ , moderately stained; + , weakly stained; - , negatively stained; NA, not available.

${ }^{a}$ Autopsy case.

* Same case.

spectively, and one case was negative for MT (Fig. 2; Table 1). All three cases of glucagonomas were negative for MT (Table 2). Among 10 cases of gastrinomas, 3 cases were strongly positive, 3 cases were moderately positive, and 4 cases were weakly positive for gastrin (Table 3). Five cases were weakly positive and five cases were negative for MT (Fig. 3; Table 3). Among six cases of PPomas, two cases were moderately positive and four cases were weakly positive for PP, whereas two cases were weakly positive, and four cases were negative for MT (Fig. 4; Table 4). Among three cases of nonfunc-

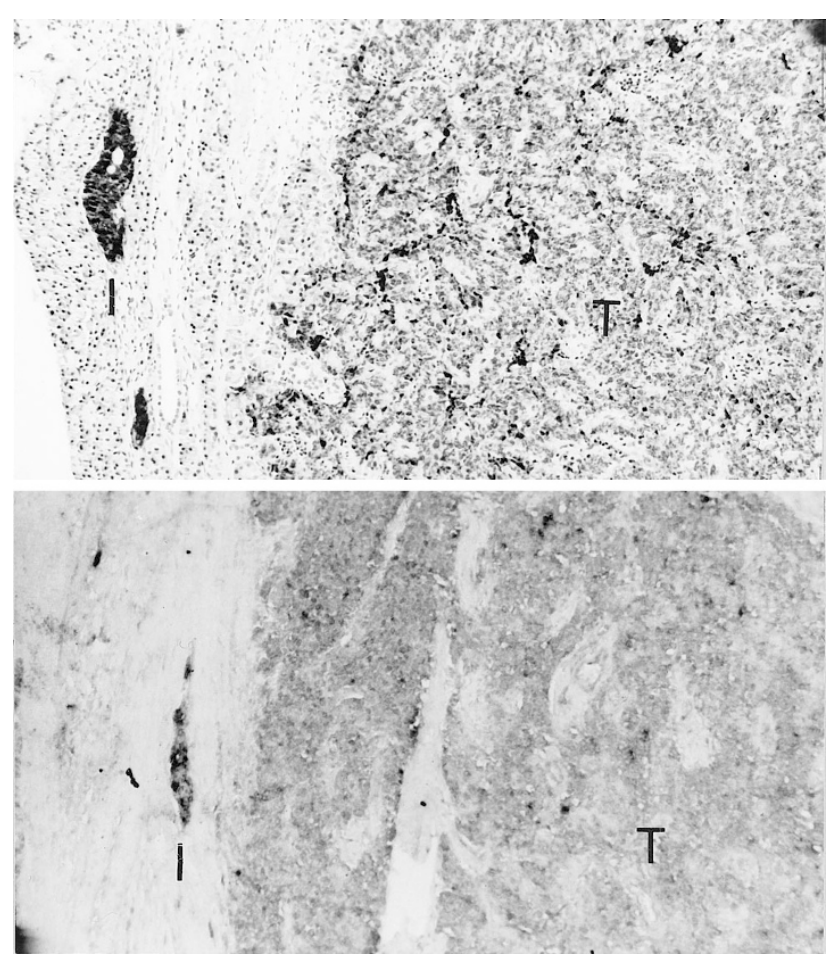

FIGURE 2. Insulinoma Case 4. The non-neoplastic islets (I) in the adjacent normal pancreas were strongly positive for both insulin and metallothionein, whereas insulinoma cells (T) were moderately stained for both insulin and metallothionein. Immunostained for insulin (A) and metallothionein $(\mathbf{B})(265 \times)$. tioning endocrine neoplasms, all were negative for the four pancreatic hormones and gastrin but were positive for chromogranin A, in which one case was weakly positive and two cases were negative for MT (Fig. 5; Table 5).

\section{DISCUSSION}

MTs are widely and ubiquitously distributed in many mammalian tissues $(1,18,19)$. The present study revealed preferential immunolocalization of MT in human pancreatic islets. The presence of MT in human islets corresponds to the concomitant presence of zinc and MMPs in islet tissue. The histochemical presence of zinc in human islets has been recognized since the 1960 s $(7,8)$ as $\beta$ islet cells contained trace amounts of zinc, which binds to the B-5 histidine of the insulin molecule. The preferential presence of MMPs in islets was discovered in the 1990s $(10,11)$. MMP and tissue inhibitor of metalloproteinase homeostasis is involved in remodeling, differentiating, and dedifferentiating processes in both normal islets and pancreatic endocrine neoplasms (10). The further finding of MT immunoreactivity in pancreatic endocrine neoplasms suggests the participation of MT in zinc homeostasis and metabolism and implicates a more complex role for zinc in pancreatic hormone synthesis and secretion $(10,11)$. Among the four distinct islet cell types, $\beta$ cells were more strongly stained than non- $\beta$ cells for MT. The current study with pancreatic endocrine neoplasms disclosed that non- $\beta$ cell tumors, including ectopic hormoneproducing gastrinoma, were also positive for MT, although the staining intensity was weaker for non- $\beta$ cell tumors than for insulinomas. This positive staining further supports the presence of MT in all four islet cell types and pancreatic endocrine neoplasms. It was evident that immunocytochemical staining for MT was somewhat weaker for pan- 
TABLE 2. Summary of Islet Cell Tumors and MT Immunostaining in Glucagonomas

\begin{tabular}{|c|c|c|c|c|c|c|c|}
\hline \multirow{2}{*}{ Case No. } & \multirow{2}{*}{ Age/Sex } & \multirow{2}{*}{ Location } & \multirow{2}{*}{ Size $(\mathrm{cm})$} & \multicolumn{2}{|c|}{ Glucagon Staining } & \multicolumn{2}{|c|}{ MT Staining } \\
\hline & & & & Islets & Tumor & Islets & Tumor \\
\hline 1 & $43 / \mathrm{F}$ & Head/Tail & $18 \times 10 \times 8$ & +++ & + & +++ & - \\
\hline 2 & $60 / \mathrm{F}$ & Liver metastasis & & NA & + & NA & - \\
\hline $3^{a}$ & $68 / \mathrm{M}$ & Tail & $0.2 \times 0.1$ & +++ & ++ & +++ & - \\
\hline
\end{tabular}

MT, metallothionein; +++ , strongly stained; ++ , moderately stained; + , weakly stained; - , negatively stained; NA, not available.

a Autopsy case.

TABLE 3. Summary of Islet Cell Tumors and MT Immunostaining in Gastrinomas

\begin{tabular}{|c|c|c|c|c|c|c|c|}
\hline \multirow{2}{*}{ Case No. } & \multirow{2}{*}{ Age/Sex } & \multirow{2}{*}{ Location } & \multirow{2}{*}{ Size $(\mathrm{cm})$} & \multicolumn{2}{|c|}{ Gastrin Staining } & \multicolumn{2}{|c|}{ MT Staining } \\
\hline & & & & Duodenum & Tumor & Duodenum & Tumor \\
\hline 1 & $29 / F$ & Head & $1.5 \times 1.0$ & +++ & ++ & ++ & + \\
\hline 2 & $31 / \mathrm{M}$ & LN metastasis & & NA & ++ & NA & + \\
\hline 3 & $31 / \mathrm{M}$ & Liver metastasis & & NA & + & NA & - \\
\hline 4 & $44 / \mathrm{F}$ & Duodenum & $0.8 \times 0.6$ & +++ & +++ & ++ & + \\
\hline 5 & $45 / \mathrm{F}$ & Liver metastasis & & NA & + & NA & - \\
\hline 6 & $47 / F$ & Duodenum & $1.5 \times 1.0$ & +++ & +++ & + & - \\
\hline 7 & $50 / \mathrm{F}$ & Liver metastasis & & NA & ++ & NA & + \\
\hline 8 & $54 / \mathrm{M}$ & Duodenum & $1.0 \times 1.0$ & +++ & + & + & - \\
\hline 9 & $57 / \mathrm{M}$ & Liver metastasis & & NA & + & NA & - \\
\hline 10 & $68 / \mathrm{M}$ & Liver metastasis & & NA & +++ & NA & + \\
\hline
\end{tabular}

MT, metallothionein; LN, lymph node; +++, strongly stained; ++, moderately stained; +, weakly stained; -, negatively stained; NA, not available.

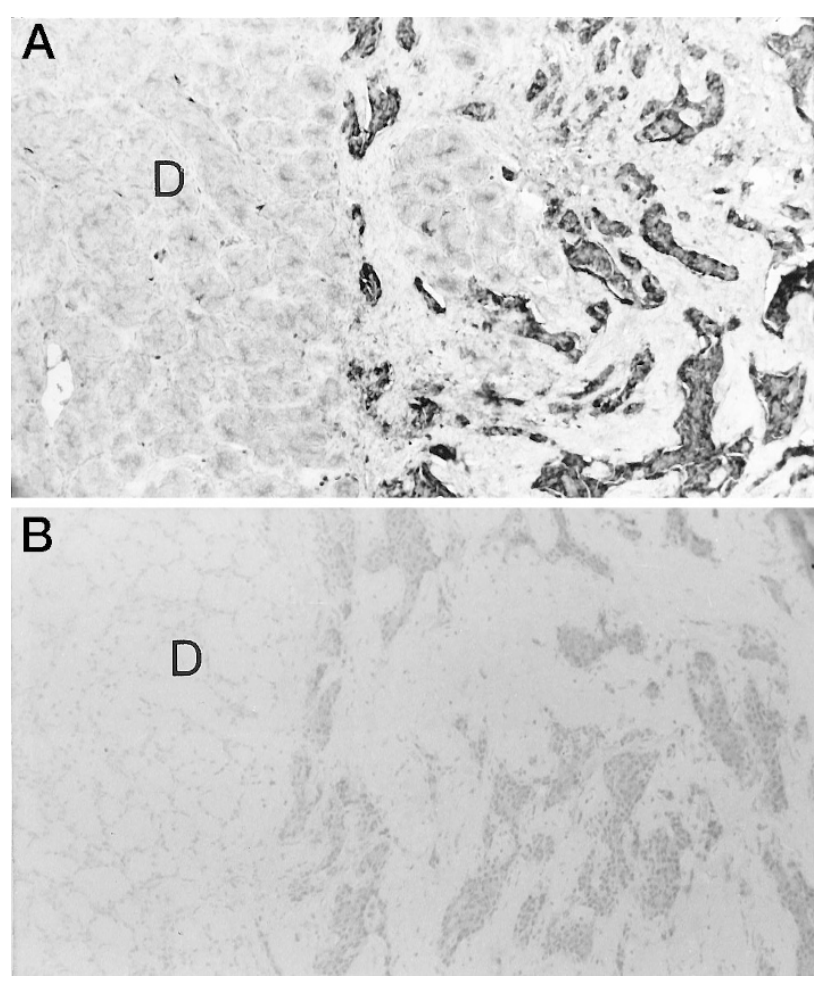

FIGURE 3. Gastrinoma Case 4. The gastrinoma cells were strongly and weakly positive for gastrin and metallothionein, respectively. Immunostained for gastrin (A) and metallothionein (B) $(265 \times)$. D, duodenal mucosa.

creatic endocrine neoplasms as compared with the staining intensity for MT in the normal islets. This lesser staining for MT in pancreatic endocrine neoplasms parallels the lower zinc content in pancreatic endocrine neoplasms (9). The lower zinc in pancreatic endocrine neoplasms may require less MT for homeostasis and detoxification; however,
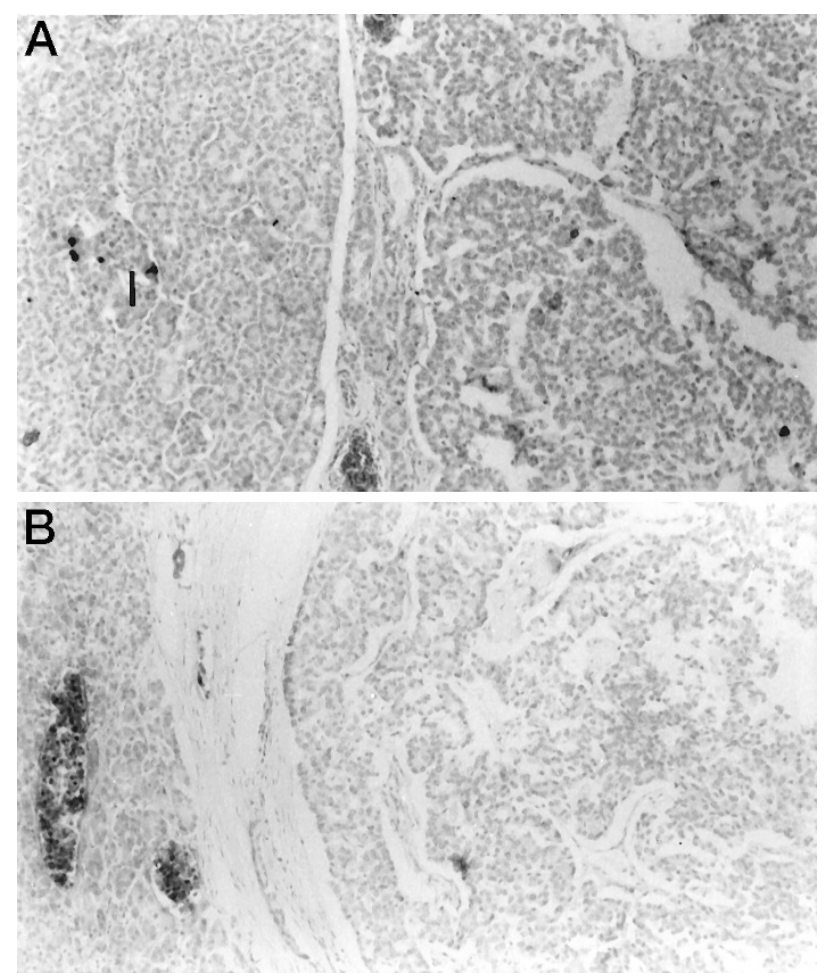

FIGURE 4. Pancreatic polypeptide (PP)-oma Case 1 . There were a few PP cells in the normal islet (I), but the tumor cells were diffusely weakly stained for PP. Metallothionein staining was positive for the normal islet but negative for the tumor cells. Immunostained for PP (A) and metallothionein $(\mathbf{B})(265 \times)$.

the exact reason for the lower content of MT in pancreatic endocrine neoplasms is unknown.

MT levels are elevated in certain tumors $(20,21)$, including breast cancers $(22,23)$, prostate carcinomas $(24,25)$, testicular embryonal carcinomas (26), renal cell carcinomas (27), thyroid tumors (28), brain tumors (29), and others (2, 21, 30, 31). MT 


\begin{tabular}{|c|c|c|c|c|c|c|c|}
\hline \multirow{2}{*}{ Case No. } & \multirow{2}{*}{ Age/Sex } & \multirow{2}{*}{ Location } & \multirow{2}{*}{ Size $(\mathrm{cm})$} & \multicolumn{2}{|c|}{ PP Staining } & \multicolumn{2}{|c|}{ MT Staining } \\
\hline & & & & Islets & Tumor & Islets & Tumor \\
\hline $1^{a}$ & $26 / F$ & Head & $1.5 \times 1.0$ & +++ & + & ++ & - \\
\hline $2^{*}$ & $33 / \mathrm{M}$ & Body/Tail & $15 \times 14 \times 13$ & +++ & + & ++ & + \\
\hline $3^{*}$ & $35 / \mathrm{M}$ & Liver metastasis & & NA & + & NA & + \\
\hline 4 & $68 / \mathrm{F}$ & Tail & $6.0 \times 6.0$ & +++ & + & ++ & - \\
\hline 5 & $70 / \mathrm{F}$ & Liver metastasis & & NA & ++ & NA & - \\
\hline 6 & $74 / \mathrm{F}$ & Head & $1.1 \times 1.0$ & +++ & ++ & +++ & - \\
\hline
\end{tabular}

PP, pancreatic polypeptide; MT, metallothionein; +++, strongly stained; ++, moderately stained; +, weakly stained; -, negatively stained; NA, not available.

a Autopsy case.

* Same case.

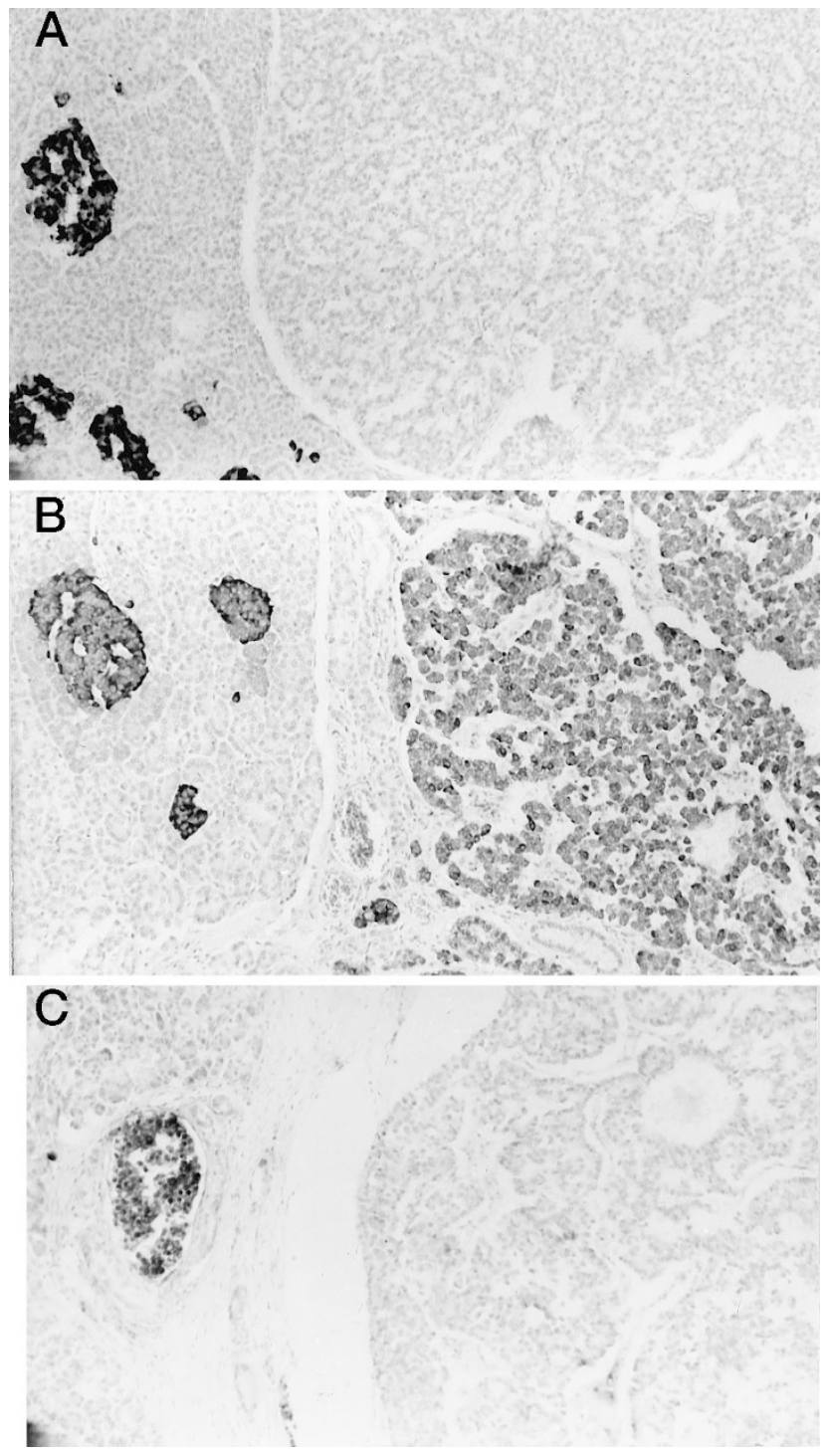

FIGURE 5. Nonfunctioning tumor Case 2. The tumor cells were negative for four pancreatic hormones, gastrin, and metallothionein but positive for chromogranin A. Immunostained for insulin (A), chromogranin A (B), and metallothionein (C) $(265 \times)$.

overexpression has been implicated in resistance to radiotherapy (31) and toxicity to chemotherapy (32). MT overexpression in breast cancers seems to be associated with a poorer prognosis $(22,23)$. In all cases of pancreatic endocrine neoplasms in this study, there is no MT overexpression as compared with that of stronger stained normal islets (Tables $1-5)$. There is no implication that MT overexpression is correlated to poor prognosis for pancreatic endocrine neoplasms as benign insulinomas were more positive for MT than were clinically malignant and potentially malignant non- $\beta$ cell tumors.

Regarding the possible cross-reaction of rabbit antimouse MT I antibody to human MT I, at least 11 isozymes of human MT I are known, in which the terminal 15 amino acids in the humans are conserved and are NacMDPNCSCATGGSCSCamide (33). This amino acid sequence differs by two amino acids from that of mouse/rat MT I (1). The good immunocytochemical staining for human MT observed in this study suggests an adequate crossreaction between the antimouse MT I and human MT I found in human islets and pancreatic endocrine neoplasms. This rabbit antimouse MT I antibody cross-reacts with mouse MT II, which has four amino acid substitutions in the terminal 15 amino acids compared with mouse MT I (1). MTs are relatively well preserved in many species of animals as $56 \%$ of all amino acid residues are conserved in the 37 mammalian MTs reported (1). The commercially available mouse antihorse MT I antibody has been widely used for human tissues with good crossreactivity (2-4). The terminal horse MT I is NacMDPNCSCVAGGSCTCamide (34) and differs by three amino acids from that of human MT I.

It is fairly reasonable to speculate that MT is preferentially present in pancreatic islets based on these immunocytochemical staining results. Furthermore, because pancreatic tissue contains 100 $\mu \mathrm{g} / \mathrm{g}$ wet weight of zinc (9), a functional role for MT in pancreas seems reasonable (35). MT is at least involved in zinc homeostasis and metabolism in pancreatic islets. The presence of zinc-containing MMPs in islets coincides with the presence of MT in islets. It is also conceivable that MT may modulate pancreatic hormone secretion as less staining for MT is detected in pancreatic endocrine neoplasms, which generally store fewer hormones than normal 
TABLE 5. Summary of Islet Cell Tumors and MT Immunostaining in Nonfunctioning Tumors

\begin{tabular}{|c|c|c|c|c|c|c|c|}
\hline \multirow{2}{*}{ Case No. } & \multirow{2}{*}{ Age/Sex } & \multirow{2}{*}{ Location } & \multirow{2}{*}{ Size $(\mathrm{cm})$} & \multicolumn{2}{|c|}{ CHG Staining } & \multicolumn{2}{|c|}{ MT Staining } \\
\hline & & & & Islets & Tumor & Islets & Tumor \\
\hline 1 & $42 / \mathrm{F}$ & Body/Tail & $11 \times 8 \times 5$ & +++ & +++ & ++ & + \\
\hline $2^{a}$ & $66 / \mathrm{F}$ & Body & $0.8 \times 0.4$ & +++ & +++ & ++ & - \\
\hline $3^{a}$ & $80 / \mathrm{F}$ & Tail & $1.0 \times 0.7$ & +++ & +++ & ++ & - \\
\hline
\end{tabular}

CHG, chromogranin A; MT, metallothionein; +++ , strongly stained; ++ , moderately stained; + , weakly stained; - , negatively stained; NA, not available.

${ }^{a}$ Autopsy case.

islet cells. However, further studies are needed to clarify the interrelationships of pancreatic hormone synthesis and secretion with zinc, MMPs, and MT in human islets.

Acknowledgments: The rabbit antimouse MT I was kindly provided by Dr. Glen Andrews, Department of Biochemistry, University of Kansas Medical Center.

\section{REFERENCES}

1. Kaji JHR. Overview of metallothionein. Methods Enzymol 1991;205:613-26.

2. Kuo T, Lo SK. Immunohistochemical metallothionein expression in thymoma: correlation with histological and cellular origin. Histopathology 1997;30:243-8.

3. van den Oord JJ, Sunardhi-Widyaputra S, van Damme B. Monoclonal antibody to liver metallothionein: a novel marker for myoepithelial cells. Pathol Res Pract 1993;189: 1187-90.

4. van de Oord JJ, De Ley M. Distribution of metallothionein in normal and pathological human skin. Arch Dermatol Res 1994;286:62-8.

5. Danielson KG, Ohi S, Huang PC. Immunochemical detection of metallothionein in specific epithelial cells of rat organs. Proc Natl Acad Sci U S A 1982;79:2301-4.

6. Cherian MG. The significance of the nuclear and cytoplasmic localization of metallothionein in human liver and tumor cells. Environ Health Perspect 1994;102(Suppl):131-5.

7. Okamoto K, Kawanishi H. Submicroscopic histochemical demonstration of intracellular reactive zinc in beta cells of pancreatic islets. Endocrinol Jpn 1966;13:305-18.

8. Pihl E. An ultrastructural study of the distribution of heavy metals in the pancreatic islets as revealed by sulfide silver method. Acta Pathol Scand 1968;74:145-60.

9. Tomita T. Zinc content of pancreatic tumors of islet cell origin. J Natl Cancer Inst 1970;44:329-37.

10. Tomita T, Iwata K. Gelatinases and tissue inhibitors of gelatinases in pancreatic islets and islet cell tumors. Mod Pathol 1997;10:47-54.

11. Tomita T, Iwata K. Matrix metalloproteinases and tissue inhibitors of metalloproteinases in some endocrine organs and their tumors. Endocr Pathol 1999;10:15-26.

12. Cattoretti G, Becker MGH, Key G, Duckrow M, Shutter C, Galle J. Monoclonal antibodies against recombinant parts of Ki-67 antigen detect proliferating cells in microwaveprocessed, formalin-fixed, paraffin sections. J Pathol 1992; 168:357-63.

13. Solcia E, Sessa F, Rindi G, Bonato M, Capella C. Pancreatic endocrine tumors: general concepts; nonfunctioning tumors and tumors with uncommon function. In: Dayal Y, editor. Endocrine pathology of gut and pancreas. Boca Raton: CRC Press; 1991. pp. 105-31.

14. Tomita T, Matsubara O. Immunocytochemical localization of me- tallothionein in human pancreatic islets. Pancreas 2000;20:21-4.

15. Tomita T, Iwata K. Matrix metalloproteinases and tissue inhibitors of metalloproteinases in colonic adenomasadenocarcinomas. Dis Colon Rectum 1996;39:1255-64.

16. Kaji JH, Schaffer A. Biochemistry of metallothionein. Biochemistry 1988;27:8509-15.

17. Andrews GK, Gage P, Palmiter P, Thomas PP, Sarras MPJ. Metal ions induce expression of metallothionein in pancreatic exocrine and endocrine cells. Pancreas 1990;5:548-54.

18. Dalton TD, Fu K, Enders GC, Palmiter RD, Andrews GK. Analysis of the effects of over-expressed metallothionein-I in transgenic mice on reproductive toxicology of cadmium. Environ Health Perspect 1996;104:68-70.

19. De Lisle RC, Sarras MPJ, Hidalgo J, Andrews GK. Metallothionein is a component of exocrine pancreas secretion: implication for zinc homeostasis. Am J Physiol 1996;271: C1103-10.

20. Murphy D, McGown AT, Crowther D, Mander A, Fox BW. Metallothionein levels in ovarian tumors before and after chemotherapy. Br J Cancer 1991;63:711-4.

21. Jasani B, Schmid KW. Significance of metallothionein overexpression in human tumours. Histopathology 1997;31:211-4.

22. Fresno $\mathrm{M}, \mathrm{Wu} \mathrm{W}$, Rodriguez JM, Nadji M. Localization of metallothionein in breast carcinomas: an immunohistochemical study. Virchows Arch A Pathol Anat 1993;423:215-9.

23. Goulding H, Jasani B, Pereira H, Reid A, Galea M, Bell JA. Metallothionein expression in human breast cancer. Br J Cancer 1995;72:968-72.

24. Moussa M, Kloth D, Peers G, Cherian MG, Frei JV, Chin JL. Metallothionein expression in prostatic carcinoma: correlation with Gleason grade, pathologic stage, DNA content and serum levels of prostatic specific antigen. Clin Invest Med 1997;20:371-80.

25. Zhang XH, Li J, Sakamoto H, Takenaka I. Immunohistochemical localization of metallothionein in human prostate cancer. J Urol 1996;156:1679-81.

26. Kontozoglou TE, Banerjee D, Cherian MG. Immunohistochemical localization of metallothionein in human testicular embryonal carcinoma cells. Virchows Arch A Pathol Anat 1989;415:545-9.

27. Zhang XH, Takenaka I. Incidence of apoptosis and metallothionein expression in renal cell carcinoma. Br J Urol 1998; 81:9-13.

28. Hartey I, Cherian MG, Banerjee D. Immunohistochemical localization of metallothionein in human thyroid tumors. Am J Pathol 1987;129:177-82.

29. Maier H, Jones C, Jasani B, Ofner D, Ziegler B, Schmid KW, et al. Metallothionein overexpression in human brain tumors. Acta Neuropathol 1997;94:599-604.

30. Zelger B, Hittmair A, Schir M, Ofner D, Fritsch PO, Bocker W, et al. Immunohistochemically demonstrated metallothionein expression in malignant melanoma. Histopathology 1993;23:257-64. 
31. Renan MJ, Dowman PI. Increased radioresistance of tumour cells exposed to metallothionein-inducing agents. Radiat Res 1989;120:442-5.

32. Kaina B, Lorrer H, Karin M, Herrlich P. Overexpressed human MT II gene protects Chinese hamster ovary cell from killing by alkylating agents. Proc Natl Acad Sci U S A 1990; 87:2710-4.

33. Lambert E, Kille P, Swaminathan R. Cloning and sequencing a novel metallothionein I isoform expressed in human reticulocytes. FEBS Lett 1996;389:210-2.

34. Kojima Y, Berger C, Vallee BL, Kagi JHR. Amino-acid sequence of equine renal metallothionein-1B. Proc Natl Acad Sci U S A 1976;73:3413-7.

35. Fu K, Tomita T, Sarras MP Jr, DeLisle RC, Andrews GK. Metallothionein protects cerulein-induced acute pancreatitis. Pancreas 1998;17:238-46.

\section{Book Review}

\section{Bowcock AM (ed): Breast Cancer Molecular Ge- netics, Pathogenesis and Therapeutics, 582 pp, Totowa, NJ, Humana Press, 1999 (\$145).}

This book is primarily for medical and research personnel whose focus is breast cancer. It represents a state-of-the-art review of current and future research directions in breast cancer treatment, diagnosis, and pathogenesis. This multiauthored text is divided into three sections: etiology, biology of tumor progression, and therapeutics and diagnostics.

The first section, consisting of 10 chapters, is titled "Etiologies." This section includes in-depth discussion of the molecular and genetic alterations that play a role in breast cancer development. BRCA 1 and 2; oncogenes; and tumor suppressor genes, including growth factors, Her2/ $n e u, p 53$, and apoptotic pathways, are discussed in detail. An attempt is made to correlate the genetic alterations with different stages of tumor progression from atypical ductal hyperplasia to carcinoma, and the clinical relevance of each marker is discussed. Three chapters are dedicated to hereditary breast cancer genes with excellent review of epidemiology, clinical expression of gene alteration, biologic function of protein, and genetic counseling. Lacking, however, is information for determining specific risk assessment based on pedigree, a practical piece of information.

The second section, "Biology of Tumor Progression," includes chapters that focus on the interplay between tumor stroma and breast cancer progression. Angiogenesis and proteolytic enzyme systems, including matrix metalloproteineases and NM23, are discussed.

The third section, "Therapeutics and Diagnostics," includes excellent discussions on the mechanism of action and uses of current and newer chemotherapies in the treatment of breast cancer. Immunotherapy (i.e., anti-Her2/neu and anti-MUClag), metalloproteinase inhibitors, and hormone manipulations are discussed. Mechanisms of drug resistance are detailed. This book is well organized, expertly written, and comprehensive.

The references are extensive, although some are already dated. Although a large part of the text deals with basic research, the translational aspect of the information is emphasized and provides relevant clinical correlations whenever possible. Another strength is that most chapters conclude with a summary of the salient points. The negative aspects of this book is that it is highly compact with information and as with any research text is quickly dated.

The approach to breast cancer treatment is multidisciplinary, which requires a knowledge of the disease outside of your own subspecialty practice. Although this book does not specifically address the practice of general pathology, it provides important information for pathologists who are heavily involved with breast cancer, especially if part of a team of specialists.

\section{Susan Ann Fineberg \\ Montefiore Medical Center \\ Bronx, New York}

